\title{
KUDÜS ve DEVLETLER HUKUKU
}

\author{
Prof. Dr. Türkkaya ATAÓV
}

\section{Gtris :}

"Kudüs" bir kentin adı olmaktan çok daha öte bir anlam ve değer taşır. Üç monoteist dine, yani Yahudiliğe, Huristiyanliğa ve Müslümanlıð̆a inananlar için "Kutsal Kent"'tir. Yahudiler kentin adının ilk kez Tevrat'ta geçmesiyle kutsallı̆̆ ve ebediliğinin Kral Dávud ve Süleyman'ın (Salomon) yönetimiyle bağlantılı olduğuna inanırlar. Gerçekten, Tevrat'ta (ve Inoil'de) Kudüs şiir gibi ince duygularla tanımlanır. Örneğin, Mezmur'un bir yerinde (48:3/2) "tüm dünyanun sevinci", başka bir yerinde de $(50: 2)$ "kusursuz güzellik" diye geçer. Mersiyeler'de de $(1: 1)$ "kentlerin prensesi" diye anılır. Birçok Yahudi yayını eski Kudüs'ün parlaklığıyla haklı olarak övünür. Burası, en başta M.Ö. 950'de yapllan ve gene M.Ö. 515'de Bâbilliler'in yıktığı, Yahudilerin buraya bir daha dönmeleriyle gene yapturilan ve M.S. 70'da Romalılara baş kaldırdıklan sırada yıkılan Süleyman Tapınağı olmak üzere, Yahudiler için, kuşkusuz, bir miknatıs gibi çekici olmuştur. Ama hemen ekleyelim ki, bunu söylemek başka, Yahudi dini ile asla aynı şey olmayan Siyonizmin, İsrail devletinin kurulmasından sonra askerî saldırılarla toprak elde etmesinin "Peygamber İbrahim'e yapılan vaad"'n yerine getirilmesi biçiminde yorumlamak bambaşka bir şeydir.

Filistin'in tbrahim'den olacaklara verileceğine dair din kitaplarında yazllanlar, Siyonizmin yaptığı dar yorum çerçevesinde bile, yanlıştır. Bu çerçeve Içinde açık bir anlatım Tekvin'de vardır : Bugün Nablus diye bildiğimiz yerde Ibrahim'e denir ki : "Bu toprağl senin sulbüne vereceğim." $(12: 7)$ tbrahim, Bethel yakınlarında bir tepedeyken de şu sözleri duyar: "Göndügün bütün topraklan sana ve senin sülbundan olanlara ilelebet vereceğim". (13:15) Ayni kaynakta başka bir yerde (Tekvin, $15: 18$ ) daha büyük bir açıklık var : "Bu toprağı, Mısır'daki nehirden büyük nehre, Fırat Nehrine kadar senin sülbundan olanlara verdim." Aynı vaad Ishak'a ve Yakub'a da yapılır 
(28:13). Sünnet, Tanr ile İbrahim ve onun sülbundan olanlar arasındaki andlaşmanın bir göstergesi olarak kabul edildiğinde (17/8), tüm Kenân diyarını "ebedî mülk" olmak üzere İbrahim'e verir.

Ne var ki, din çerçevesi içindeki bu vaad yalnız Yahudilere yapılmış değildir. "Senin sülbundan" sözlerinden amą̧ yalnızca Yahudiler olamaz ki! Gene din çerçevesi içinde, İbrahim'in oğlu İşamel'den olanlar Müslüman ve Hiristiyan Araplardur. ${ }^{1} \mathrm{Bu}$ anlayış içinde, İşamel Arap kavimlerinin babasıdır. İbrahim'in socukları arasında bir fark olmadığını Tevrat ta söyler (Tekvin, $21: 10-12$ ). Kaldı ki, sünnet andlaşması yoluyla Kenân diyarı "ebedî mülk" olarak verildiğinde sünnet olmuş olan İşmael'di, Sarah'dan olma İshak değil - din kitaplarında Yahudilerin türediğine inanılan İshak daha doğmamıştı bile...

Kuşkusuz, önemli olan konunun hukuksal yönüdür. Bu incelemede de, asıl bunun üstünde durulacaktır. Ancak, tarihe dayandurimak istenen bazı savları da burada özetlemek ve gereken yerlerde yanitlamak zorundayz. Kudüs kenti, gene aynı nedenlerden ötürü, Hıristiyanlık için de bir kutsallık sığınağı, tarihin bir çeşit başladığı yerdir. İsa da, Huristiyanlık da orada doğmuştur. Kutsal Gömüt, Velâdet Kilisesi ve daha kırk kadar Hıristiyan tapınağı oradadır. İsa'nın doğu$\mathrm{mu}$, yaşamı ve ölümüyle ilgili tüm yerler Kudüs'te ve hemen onun çevresindedir. Ve Kudüs'te Hıristiyanlık deyince içine Roma Katoliklił̆i, Yunan ve Rus Ortodoksluğu, Ermeni, Kıptî, Marûnî ve birçok Protes$\tan$ Kilisesi girer. Kişi Kudüs'te İncil'de geçen tüm yerlerle sürekli ve fiziksel temas durumundadır. Issa'nın kente şuradan girdiğini, o yanda gözyaşı döktüğünü, beride kanını akıp ötede gömüldüğünü söyleyebilir. Kudüs'lü birçok eski Arap ailesi Hıristiyandır; kökleri Haçhlara, hattâ daha da gerilere gider. Hıristiyanlara sorarsanız, Kuđüs'ün bugün Siyonizmin sultası altında kalması, tarih ve hukuk ögretileri-

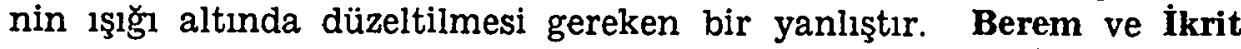
köylerinin Hıristiyan halkının başına gelenler bugünkü İsrail'in $\mathrm{H}_{1}$ ristiyan yurttaşları için de neler tasarlamakta olduğunun sembolik belirtisidir. ${ }^{2}$ İsrail yetkilileri 1948 yllında bu iki küçük köyün Hıristiyan halkına köylerinl iki hafta için terketmelerini, ancak hemen geriye dönebileceklerini söylemişler, aradan bunca yıl geçmiş olmasına karşın konutlarını bir daha görmemişlerdir!

Hiç kuşku yok ki, Kudüs İslâm ve onun simgelediği kültür için de kutsaldır. Müslümanlar (Araplar ve Türkler) bu topraklarda 1.300

1 Alfred Guillaume, "Zionists and the Bible," Christians, Zionism and Palestine, Beirut, Institute for Palestine Studies, 1970, s. 3-4.

2 Edwin M. Wright, A Tale of Two Hamlets, Cleveland, the Northeast Ohio Committee on Middle East Understanding, 1873. 
yll kadar egemen olmuşlardır. Kudüs, bütün Müslümanlar için kutsallıkta yalnız Mekke ve Medine'den sonra gelir. Kudüs'teki El-Harâm el (eş) - Şerif'ten daha kutsal ancak Mekke'de Kâbe ve Medine'deki El-Harâm olabilir. İslâm Peygamberi Muhammed dualarını, ilk başlarda, Kudüs'e dönerek okurdu. "Kıble" Mekke yönüne daha sonra çevrildi. Ama bu değişiklik bir yana, Kudüs Müslümanlık açısından da kutsal olmakta devam etmiştir. Ve yalnız Kur'andaki çeşitli sârelerden ötürü değil, Müslüman tarihinin bu kentle sarmaş-dolaş oluşundan ötürü de...

\section{KENTIN GEÇMIŞINDEKI :ÖZELLIK :}

Şimdi, kentin geçmişine ve bu geçmişin bize bıraktığı mirasa bi. raz daha yakından bakalım. Bu bakıs baz hukuksal dayanaklar için de bize sağlam hareket noktaları verecek.

Bugün "Kenânlılar" diye bildiğimiz bir Arap kavmi tâ M.Ö. 3.000 yıllarında orta Arabistan çöllerinden yukarı doğru çıkarak ulaştıklan noktada kurdukları kente (o zamanki tanrılarından ötürü) "Orasalem" demişlerdi. Tarihte Aramî ya da Bâbil kökenli kelimeler olarak "Varya Salem" ve "Yaro Salem" diye de geçiyor. Gene Kenânlıların bir kolu olan Jebusitler'den ötürü, M.Ö. 1.400 dolaylarında Kudüs'e "Jebus" dendiğini de biliyoruz. Kenân diyarı iki-yüz yıl sonra İbrani işgâline uğrad1. M.Ö. 1.000 dolaylarında Kral Dâvud, yerli halkla birlikte, Judah ve Israil kabilelerinin bir çeşit federasyonunu kurmayı başardı. Bu federasyon onun oğlu süleyman'ın ölümüyle dağıldı ve ortaya çıkan iki ayrı krallığın birinin başkenti Kudüs, ötekininki de Samiriye (Samaria) oldu. Her ikisi de Asurlular'ın batıya yönelişleriyle yıkıldı. Bâbil Kralı Nebukadnezar da Asurluları ezip kenti ve Süleyman'ın Tapınağını yerle-bir etti. Yaşamlarını yitirmeyen İsraillilerin Bâbil'e götürülmeleri ve orada kölelikleri M.Ö. 586'da başlar. Pers İmparatoru Sirus onların ancak yarım yüzyll sonra geriye dönmelerine izin verdi. Ama ancak bir kısmı döndü.

Birbirini izleyen bu işgâllerde yerli halkın bir bölüğü tọ̣rağından hiç ayrılmadı. Kudüs'te kalan Kenânlılar, onların kolu Jebusitler, hattâ kuzeyden inen Hititler Kudüs'ün ve Filistin'in yerli halkırı oluşturmağa devam etti. Büyük İskender bugün Çanakkale Boğazı dediğimiz su yolunu geçinceye kadar, bu topraklar iki-yüz yıl kadar barı̧ gördü. Iskender'in kendi Kudüs'e adımını hiç atmadiysa da, ordusunun $\mathrm{Ml}$ sir'a kadar uzanmasıyla Kudüs te 960 yıl kadar önce Batı Helen, sonra da Roma etkilerine açık kaldı. Pompey Roma adına Suriye'ye mü- 
dahale ettiğinde, Filistin de bu kanadın altına girmiş, ancak kendi kendini yönetimde bir derece özgürlük kazanmiştı. Kendi bir Arap olan fakat Yahudi din görevlisinin kızıyla evlenen hükümdar Herod'un oğullarının yönetimi karmaşıklık, saray cinayetleri ve işkencelerłe bezenmişti. Isa'nun Beytlihem'de (Bethlehem) doğuşu da bu suraya rastlar. Yahudilikten farklı bir öğretiyi yaymağa çalışan İsa'nın, çarmıha gerilmesine kadar varan çalkantıların içinde kalmaya zorlanışı ફ̧aşırtıcı olmamalı. Onun ögretisi Kudüs'te ve Filistin'de baskı altında tutulmuş, ancak başka topraklarda yayılmağa yüz tutmuştu. Ne var ki, bu baskıya yenilerinin de eklenmesiyle birbirini izleyen isyanlar İmparator Konstantin'in 325'de Hiristiyanlığ kabulüyle duruldu. Bu dinin ilk önemli yapıları işte bundan sonra görülüyor. İsa'nın çarmuha gerildiği ve gömüldügü yerde yükselen kilise bu ynllann ürünüdür.

Ancak, Perslerin sallanan Roma Imparatorluğuna bu topraklarda silleler vurmağa hazırlandıkları bir sırada, güneyde Müslümanlığı kabul etmiş olan Araplar kuzeye doğru yayllyorlardı. Müslüman Arap orduları Kudüs çevresinde ilk çadırlarını M.S. 638'de kurdular. Yarmuk Nehri Muharebesi Huristiyan direnişinin son aşaması oldu. "Kilisenin bal dilli savunucusu" diye bilinen Sofronius Araplara haber göndererek kenti yalnız Halife ömer'e teslim edeceğini duyurdu. $O$ sırada Suriye'de olan Ömer ellerindeki deveye çevresindekilerle nöbetleşe binerek Kudüs'e hiç kan akıtmadan girdi. Kentin eski sahipleriyle birlikte İslâm Peygamberinin, Cebrâil'in getirdiği Burak adì kanatlı atla göğe yükseldiğine inanlan "Kutsal Kaya"ya gitti, oradan Kutsal Gömüt Kilisesini ziyaret ederken Huristiyanlarla birlikte dua etmesi istendiğinde, kendinden sonra gelecek bazı Müslüman yöneticilerin Halife Ömer'in burada namaz kılmış olduğunu anımsayarak bu kiliseyi camiye çevirip Huristiyanların yerleşmiş haklarına bir çeşit haksızlık yapabilecekleri olasıllğını ileri sürdü ve bu öneriye uymamayı yeğledí. Daha ilerde boş bir yende namaz kıldı; bugün, burada Ömer Camil yükselmektedir. Böylece, Kudüs àlınırken ilk kez kan akmamıştı. Bu da, Arapların, bir Müslüman kavmin Kudüs topraklarına girişine rastllyor. Ömer'in Hiristiyan halkla yaptığı andlaşma da muzaffer halifenin adaletini belg'eledikten başka, Kudüs'ün 1099'da bu kez Haçlılarca teslim alınmasını izleyen olaylarla çok büyük bir çelişki oluşturuyor.

Müslüman Araplar kente "Kutsal Yer" anlamma El-Kuds dediler. Kentin sınırları aşağı, yukarı Roma ve Bizans döneminde olduğu gibı kaldı. Bundanböyle, Hac için Mekke ve Medine'ye yönelen Müslümanlar "El Beyt el-Mukaddes" (Kutsal Ev) ve daha sonra "El Kuds el-Şerî̀" (Kutsal Asil Kent) dedikleri Kudüs'e de uğruyorlard. 
Emevî döneminin (661-749) Halifelerinden Abd el-Mâlik Ibn Maravan Kutsal Kaya'nın çevresine Fl-Kubbet el-Sahra'yı yaptırmıs olmakla ünlüdür. Kutsal Kaya'yı koruyan, 20.6 metre genişliğinde ve 12.1 metre yüksekliğinde, mavi, yeşil ve yaldızl mozayiklerle bezenmiş ve sekiz köşeli bu yapı herhalde dünyada en eski İslâm anitıdır. 1780 'de yeni baştan yapılmış olan tavan işlemeleri Türk Anadolu'nun çizgi ve renklerini yansitmaktadır. Dindarların inançlarına göre, kayanın üstünde Muhammed'in ayağının izi olduktan başka, Peygamber'in göğe yükselmeğe başlamassyla birlikte bu yükselişe uymağa çauşan kayanin da havalanması üstüne bu kitleyi yere itip onun yer çekimi yasasından kopmamasını sağlayan Cebrâil'in elinin izi de vardur.

Halife Ömer zamanında bütün bu çevreye verilen "El-Aksa" adı zamanla bir caminin adı olmakla sinırlandı. Abbasî döneminin (750969) Kudüs açısından belki de en önemli eylemi bu caminin Ebu Câfer al-Mansur zamanında yeni baştan yapılmasıdır. Yer sarsıntılarıyla birkaç kez yıkılmış, zaman zaman, hele Osmanlı yönetiminde onarulmiş olan El-Aksa Camii 75 direğe oturmakta, altı ara yolu kapsamaktadir.

Kendilerini Peygamber'in kızı Fatima'ya bağllyanlar Kudüs'ü 966'da aldılar. 1033'deki şiddetli yer sarsintısı El Aksa'yı yiktı; Prof. K.A.C. Creswell'e göre, ${ }^{3}$ bugünkü cami (güneydeki Kıble duvarı dışında) bu Fatimi döneminin ürünüdür. 1071'de Anadolu'ya giren Selçuklu Türkleri altı yıl sonra Kudüs'ü ve Filistin'i aldılar. Onları ilk Haçlılar izledi. Kent 15 Temmuz 1099 'da teslim olduğunda, tarihinin en büyük katliamından birini, belki de en büyüğünü gördü. Kilisenin statüsünü etkiler endişesiyle orada dua etmekten çekinen Halife Ömer' in 460 yıl önceki âdil tavrıyla ne hazin bir çelişił... Yahudiler havralariyla birlikte yakıld, katliamdan bazı Hiristiyanlar bile kurtulamadılar ve saldıranların üstleri, başları bile akıttıkları kanla kıpkırmızlyd. El-Aksa Camiinin tepesine bir Haç oturtularak kiliseye çevrildi. Papazlar Kutsal Kaya'dan parçalar kopararak taşın ağırlığı kadar altın karşlı̆̆ında satıyorlardı. Halep'in Türk Atabeyi İmad el-Din Zengi Suriye ile Mezopotamya arasında sömürgeci yerleşim niteliğinde oturmus olan Frankların topraklarını ellerinden alınca İkinci Haçlı

3 Ealy Muslim Architecture, 2 C.. Clarendon Press, 1832-40. Aynca: R.W. Hamilton, The Structural History of the Aqsa Mosque, Jerusalem, 1948.

- Bu celişkiyi yalnzz Müslümanlar değil, Hristiyan yazarlar da vurguluyor. Orneğin: Alistair Duncan, The Noble Sanctuary: Portrait of a Holy Place in Arap Jerusalem, London, Longmans, 1972. 
Seferi başladı. Kudüs'ü 1187'de Selâhaddin El-Eyyûbî geri aldı. Sir Steven Runciman'ın "şerefli bir kişi olarak zaferin nasıl kutlanacağını gösterdi"5 dediği Eyyûbî̀nin savaş sirasında ve savaştan sonra düşmanına âdil davranışı 1099 yllındaki Hıristiyan mezalimiyle gene büyük bir çelişi tablosu yaratıyor. Aksa Camiine, daha sonra (1969) yanan mihrap ve minberi o koydurtmustu. On-ikinci Yüzyllın en iyi ahşap oymacılık örneklerinden biri olan ve Yahya bin Hamid'in yaptığı ünlü mihrap İsrail'in 1967 saldurısı ve işgâlinden iki yıl sonra caminin. başka bölümleriyle birlikte yanarak kül oldu.

Haçllların gene eline geçen Kudüs'ü genç Memlûk (1247-1517) komutanı Baybars aldı. 1517'de Kudüs te, Kahire de Türklere geçti. Bu toprakları Osmanlı yönetimine (1517-1917) Yavuz Sultan Selim katmışsa da, Kudüs'te daha fazla iz bırakan Kanunî Sultan Süleyman oldu. 1537-41 yıllarında kentin çevresindeki surları yeni baştan yaptırdı, 1545-46'da cami kubbelerinin altını çinilerle döşetti. Yaptıkları kuzeydeki "El Bab el-Cenne", yani Cennet Kapısı'nın üstünde yazll. Daha sonraki sultanlardan Osman (1752), Mahmud (1817), Abdülmecid (1853), Abdülaziz (1874) ve Abdülhamid (1876) temelli onarim ve eklemelerle bu yapılara ve kentin kutsallığına sahip çıtıtlar. İslâm anitları olarak, buraya kadar sözü edilmiş olan önemli yapıların yanıbaşında, Kubbet el-Silsile, Sebil Kait Bey, Kubbet el-Arvah, Kubbet el Mi'raj, Kubbet el-Halili, Sebil el-Süleyman, Bab el-Atim, Bab Hittah, Bab el-Esbet ya da Kursi Süleyman gibi kubbe, sebil, minber, kapı ve tahtlar vardir.

Osmanlı Türkleri, Araplar gibi, Huristiyanlara ve Yahudilere anlayış ve saygı gösterdiler. Zamanına göre oldukça ileri bir "federalizm" anlayışı olarak da değerlendirilebilecek olan Osmanlı "millet" sistemine göre, Yahudiler de, Huristiyanlar da "Ehl-i Kitap"dı. Üç dini izleyenlerin hakları teamüle dayalı olarak olduğu gibi korunuyor, hattâ yüzylllar boyunca yerleşmiş olan haklar 1757 Fermanı ile yazılı duruma da getiriliyordu.

Özetle, geçmişte Kudüs'ü Yahudiler de, Hıristiyanlar da, Müslümanlar da yönetmişlerdi. Yahudi yönetimi herhalde 600 yllı geçmiyor. Hıristiyan yönetimi iki Bizans dönemi (323-614 ve 628-637), Kudüs Lâtin Krallığı (1100-1187), İkinci Frederick'in işgâli (1229-1239) ve İngiliz Mandası (1922-1948) olmak üzere, toplam 423 yıldır. Müslümanlar ise (Araplar ve Türkler) Kudüs'e 1.300 yll kadar egemen oldular. Müslüman olmayan Arapların yönetimi daha da fazlaya çıar.

Osmanlı yönetiminde, Kudüs'teki Araplar imparatorluk içindeki Türklerle yalnız Kudüs kentinde değil, imparatorluğun herhangi bir 
yerinde eşittiler. Kudüs'te kendi kendilerini büyük ölçüde yönettikleri gibi, devlet çarkında en sorumlu mevkilere atanıyorlardı. Bugünkü sözcüklerle başbakan, bakan, vali, kaymakam, asker, yargiç ve meclislerde temsilci oluyorlardı. Bugünkü Kudüs'te ise, Araplar Filistinli, Batıl, Doğulu ve derileri renkli Yahudilerden sonra kendi ülkelerinde dördüncü sınıf yurttaştırlar. Osmanlı yönetiminin fiilen sona erdiği 1917 yllından bu yana ne büyük değişiklik, ne büyük çeliş̧ ve ne büyük gerileme...

Bu gerileme, Arap hakları ve hukuku açısından, Ingiliz Manda yönetimi ile birlikte başlamıştır.

\section{INGILIZ MANDASINDA KUDÜs :}

$\mathrm{Bu}$ incelemenin konusu Kudüs'le, hattâ bu kentin devletler hukuku açısından statüsü ile ilgili olduğundan, Filistin sorununa genel olarak ya da aynı sorunun başka yönlerine değinen noktalar burada ele alınmamaktadır. Örneğin, 1917 tarihli Balfour Bildirisinin bir değerlendirmesi ve eleştirisinin yeri, uymak zorunda olduğumuz sınırlar çerçevesinde, burası değildir. Ama tüm Filistin'de Manda yönetimini kuran kararnn 13 ve 14'üncü Maddeleri Kudüs'le doğrudan doğruya ilgili oldư̆u gibi, bazı olaylar, özellikle Batı Duvarı'na ilişkin uluslararası komisyonun değerlendirmeleri konumuz açısından önemlidir.

Önce, ulusların ya da halkların kendi geleceklerini kendilerinin saptamaları ilkesi (self-determination) Birinci Cihan Savaşı ve sonrasunın bir ürünüydü. Ne var $\mathrm{ki}$, bu ilke ortaya atılır, tartışılır ve bazı uluslarca ciddiye alınırken, sömürgecilik ve emperyalizm hálâ uluslararası ilişkiler sisteminin bir parçasıydı. Savaştan sonra kurulan ve, başta İngiltere olmak üzere, galip devletlerin büyük etkisi altında olan Milletler Cemiyeti yenik devletlerden Osmanl Imparatorluğunun bazı eski toprakları üstünde "Manda" adıyla anılmağa başlanan bir sistem kurdu. Bu anlayış içinde, Filistin, Kudüs de dahil olmak üzere, 1922'de Ingiliz Mandasina verildi. Ancak, hemen belirtmek gerekir ki, bu topraklar birinden alınıp başka birine verilirken, savaş sirasında ve sonra çok sözü edilen "self-determination" ilkesine uyularak Filistin halkına oyunu soran olmamıştı. Oysa, Milletler Cemiyeti Misakı bu ilkeye uyulmasin istemekteydi. Filistin'in (ve Kudüs'ün) durumunda Manda yönetiminin yerli halkın oyuna baş vurmadan uluslararası bir örgütün kararıyla kurulması hukukun çiğnenmesidir.

Kaldı ki, yukarda sözü edilen Madde 13 Kutsal Yerler'de "mevcut hakların korunması" için Manda yöneticisi olan devlete şöyle bir sorumluluk yüklüyordu : 
“...Mevcut hakların korunmasi ve (Kutsal Yerler'e) özgürce girebilme de dahil olmak üzere, Kutsal Yerler'e ilişkin tüm sorumluluk...Mandater devlete aittir...Bu Mandada, hiçbir şey Mandater otoriteye Müslümanlar için kutsal olan ve dokunulmazlıklam garanti edilmiş bulunan anitların kuruluşuna ve yönetimine kanşma biçiminde yorumlanamaz."

Aynı belgede Madde 14 çeşitli dinsel toplulukların Kutsal Yerler'e ilişkin hak ve savlarını incelemek, tanumlamak ve saptamak üzere bir Özel Komisyon kurulmasinı öngörüyordu.

Manda yönetimiyle birlikte Filistin'e (ve Kudüs'e) yı̆̆ınsal Yahudi göçleri başladı. Bu göçün birdenbire artmasının nedenlerinden olarak Manda yöneticisi Ingilizlerin özellikle ünlü Siyonistler arasindan seçilmeleri gibi önemli noktalarn değerlendirilmesi ya da dışardan gelen Yahudi göçmenlerin yerli halka karşı tavrı ve bununla bağlantılı birçok önemli noktalar, konurnuzun burada sinurlı oluşundan ötürü şu satırlarda ele alınmayacaktır. Ancak, birden huzlanan Yahudi göçü yeni gelenlerle eski yerliler arasında doğal olarak bir sürtüşme yaratmıs, bu durum gitgide kanlı bir aşamaya varmıştır. Bu oluşumun bir parçası olarak, fakat Kudüs'ü dcğrudan doğruya ilgilendíren bir nokta Arapça El-Burak ve İbranice de Kothel Maaravi denilen ve daha çok Batı (ya da Ağlama) Duvarı diye bilinen anıtın kullanımına ilişkin uluslararası bir komisyonun vardığı sonuçlardır.

Kudüs'teki Kutsal Yerler'de ilgili tarafların hak ve hukuku geçmişte karşılıkh saygı ve teamülden kaynaklanarak ortaya çıkmıştı. Uygulama statükoya, yani mevcut duruma dayanıyordu. Biraz yukarda Müslümanların bu statükoya ne denli saygllı olduklarını gördük. Ancak, Manda rejiminin kurulmasıyla, haklarından çok daha fazlasını almağa yönelik genel bir tasarıyı hemen uygulamaya koyulan Siyo. nistler Batı Duvarı'ndaki statükoyu da birtakım zorlamalarla değiştirmeyi denediler. Bu zorlamaların neden olduğu olaylar̀da, 1929 yılinda, epeyi kan aktı. Filistin'e Milletler Cemiyeti'nin onayıla bir Uluslararası Araştırma Komisyonu göndermekten başka çıkar yol kalmamiştı.

Komisyon Araplarla Yahudiler arasında Batı Duvarn'nın kullan1mina ilişkin anlaşmazlı̆̆ inceleyecek ve bir karara varacaktı. Filistin'e 19 Haziran 1930'da ulaşan Komisyon, Kudüs'te kaldığı bir ay içinde, tüm anıtların özel niteliklerini araştırdı, anlaşmazlığa katkısı olan yan konuların üstünde durdu ve bu arada elli-ikl tanık dinledi.

Statükonun ne alduğu, yanı Yahudilerle Müslümanların haklar1- 
nun nerede başlayıp nerede bittiğine dalr güvenilir bir kaynak olarak kabul edilen Komisyon kararlar şöyle özetlenebilir :

"Bir Vakıf mülkü olan Haram el-Şerîf'in aymlmaz bir parçası olması nedeniyle, Batı Duvarinın tek sahibi ve mülkiyet hakkı olan tek kaynak Müslümanlardir.

"Duvarnn önündeki Döşeme (kaldırm) ve... Duvarın tam karşısında Mağribî (Fas) Mahallesi denilen yer de Müslümanlara aittir.

"Yahudilerin Duvar yanına...tapınma ya da başka amaçlarla getirecekleri eşyalar onlara Döşeme üstünde hiçbir biçimde bir mülkiyet hakkı vermiş olmayacaktır.

"Öte yandan, Müslümanlar da (Harâm bölgesi ve Mağrîbi Mahallesinde) Vakıf mülkü içinde ve Duvar'a değinen yerlerde, Yahudilerin Döşemeye ve Duvar'a gidişlerini engeller biçimde yapılar yapmayacak ya da herhangi birini yıkıp onarmayacaklardir...

"Yahudilerin, aşağıda sözü edilecek açık kurallara uymak koşuluyla, Batı Duvan'ndan özgürce yararlanma hakkı olacaktur...

"Sinırlı bir zaman için olsa bile, Duvar'ın bulunduğu yere, oraya koymak amacıyla, herhangi bir çadır, perde ya da benzeri esya getirmek yasaklanacaktır...

"Yahudiler Duvar yakınında boynuz biçimindeki borazanlarunı çalmayacak ve Müslümanlan rahatsız etmeyeceklerdir; öte yandan, Müslümanlar da Yahudiler tapınırlarken Döşeme yakınında kendi 'zikr' törenlerini yapmayacaklar ve Yahudileri herhangi bir biçimde rahatsı etmeyeceklerdir..."6

Komisyonun vardığı bu sonuçlar 8 Haziran 1931'de yasa biçimine sokuldu ${ }^{7}$ ve Manda yönetiminin sonuna değin yürürlükte kaldr.

Siyonist Örgütü İkinci Cihan Savaşına doğrụ oluşan olaylardan ve savaş sırasında Nazilerin Yahudilere yönelttiği baskı ve mezalimden yararlandı. Filistin'e Yahudi göçünün daha da hızlanma eğilimi-

5 A History of the Crusades, 3 C., C.U.P., 1953-54.

- The Rights and Claims of Moslems and Jews in Connection with the Walling Wall at Jerusalem, Beirut, the Institute for Palestine Studies, 1968, 8. 73-76.

7 Palestine Government, Official Gazette of the Government of Palestine, Jerusalem, 8 June 1931. 
ni gösterdiği bir sırada, Manda yönetiminin almak zorunda kaldığ \$1nırlama kararları, Siyonist yerleşmelerin barış̧ı yollardan değil de zora başvurarak kurulması, bu yerleşmeler sırasında Siyonistlerin Araplara karşı tavırları gibi önemli noktalar gene konumuz dışındadır. Bu aşamada Kudüs'ün geleceği açısından yenilik 1937-1939 yllarındaki Filistin başkaldırmasını izleyen (İngiliz) Kraliyet Komisyonunun önerisidir. Arap başkaldırmasın değerlendiren Komisyon bunụn özünde Yahudilere karşı duyulan eski ve ırkçı bir antipatiden kaynaklanmağın belirttikten sonra, Filistin'in bir Arap, bir de Yahudi devleti olarak ikiye bölünmesini öneriyor, fakat Kudüs ile Beytlihem'in üç din için de kutsal oluşundan hareketle, Kutsal Yerler için Milletler Cemiyetinin denetiminde "uluslararası bir statü" istiyordu. ${ }^{8}$

Bu önerinin âdil olup olmaması bir yana, 1937'de Kudüs için böyle bir çözüm önerilmiş, fakat İkinci Cihan Savaşının çıkmasıyla bu yönde bir gelişme olmamıştı. Savaş yıllarının olayları da gene konumuz dışındadır. Burada anumsamamız gereken yalnızca, Mandacı devlet olan İngiltere'nin sorunu çözemeyerek konuyu Birleşmiş Milletler'e getirmiş olmasıdır.

\section{CORPUS SEPARATUM :}

Siyonistlerin İsrail devleti kurulmadan önce terör yöntemlerine baş vurdukları gerçeği, sivil Arapların yer yer yığınsal katliamı, hattâ Filistin toprakları üstünde bir Yahudi devleti kurabilmek için Birleşmiş Milletler Öř̈̆tü içinde Amerika Birleşik Devletleri'nin öncülüğünde çevrilen entrikalar ve Filistin'i bölmeğe yanaşmayan devletlere yapılan baskıların ilginç hikâyeleri de Kudüs ekseninde toplanan konumuzun sınırları dışındadır. Ancak, sonuç olarak, Birleşmiş Milletler Genel Kurulu 29 Kasim 1947 tarihli ve 181 (II) numaralı karariyla Filistin'de bir Yahudi ve bir de Arap devleti kurulması yönünde tavsiye kararı aldıktan başka, Kudüs'ün de "uluslararası bir rejim" altına konmasinı öngördü.

Araplar bu tavsiyeyi kabul etmediler. Onların görüşüne göre, Birleşmiş Milletler yetkilerini aşıyordu. Devletler hukukuna göre, böyle bir uluslararası örgütün Filistin toprakları üstünde bir Yahudi devleti kurma yetkisi olamazd. Yalnız İsrail devleti ileri gelenlerinin büyük bir çoğunluğu değil, göçmenlerin kendi de, büyük ölçüde, köken ve yurttaşlak yönlerinden, bu toprakların yabancisiydular. Siyonist ön-

8 Great Britain, Palestine Royal Commussion : Report, Cmd. 5479, London, H.M.S.O., 1937, s. $131,370,381-382$. 
derlerin kimi Rusya'dan, kimi Polonya'dan, kimi Güney Afrika'dan gelmişlerdi. Amerika ve Ingiltere gibi dünyanın başka bölgelerinde etkinlikleri olan Siyonist Örgütün ise, Filistin gibi bir toprak üstünde kendi dilediği biçimde yabancı bir devlet kurması kukuk açısından yalnız yanlış değil, anlamsızdı. Bu kuruluşa yalnızca Araplar değil, birçok Yahudiler de çeşitli yayınlarıyla karşı çıktılar. İsrail'e ve Siyonizme karşı Yahudilerden gelen tepkinin incelenmesi de gene konumuzun içine girmemektedir. Ancak, İsrail ne 1948'de, ne de bugün Birleşmiş Milletler Genel Kurulunun düşündüğü Yahudi devletine uyuyor. Burada vurgulamak zorundayız ki, Birleşmiş Milletler de 1947'de asıl yerli halkın kovulacağı ırkçı bir Yahudi devleti düşünmemişti.

$\mathrm{Bu}$ incelemenin hedefi açısından önemli olan şu ki, Filistin'i ikiye bölen karar bile Kudüs'ün sui generis, yani kendine özgü niteliği olduğu noktasından hareket etmişti. Bölünmeğe karşı çıkanlar ise, bağmsız, birleşmiş, federal bir Filistin devleti öneriyorlard1. Bunların tasarısında Kudüs'ün Arap ve Yahudiler için ayrı belediyeleri olacak ama "Kutsal Kent" Filistin devletine başkent görevi yapacakti.

Kudüs'ün doğu (eski) kesimi çoğunlukla Arapti. Kentin batısına, hele yeni yerleşim bölgelerine geçmiş yıllarda Yahudiler gelmişlerdi. Birleşmiş Milletler Genel Kurulunun Filistin konusunda öneriler yapmakla görevlendirdiği Özel Komite'nin (UNSCOP) tahminine bakllırsa, bütün kentte 105.000 kadar Arap, 100.000 dolayında da Yahudi vard1.9 Özel Komite raporunda Kutsal Yerler'in ve geçmişten gelen haklann korunmasın istedi. Yukarda da değinildiği gibi, Özel Komitede çogunluk Filistin'in bölünmesini, azınllk ta birleşmiş bir devlet kurulmasını istemişti. Birleşmiş Milletler Genel Kurulu birtakım baskllarla, çoğunluk raporunu yeğledi.

Ama bölme kararının Ưçüncü Bölümü Kudüs için özel bir rejim getiriyordu :

"Kudüs Kenti bir corpus separatum olarak özel bir uluslararası rejim altına sokulacak ve Birleşmis Milletler tarafından yönetilecektir. Sorumlulukları Birleşmiş Miletler adına ve Yönetici Otorite olarak Vesâyet Kurulu yüklenecektir...

"Kudüs Kenti bugünkü Kudüs belediyesini ve... çevresindeki köy ve kasabaları içerecektir.

"Vesâyet Kurulu, bu tasarının kabulünden sonra beş ay.

9 U.N., Officlal Records of the General Assembly, Secand Session, Supplement No. 11 (Document A/364, UNSCOP Report), C. I, s. 54. 
içinde...aşağıdaki özellikleri içine alan, ayrıntılı bir Kent Statüsünü hazırlayacak ve kabul edecektir.

“... Yöneten Otorite şu amaçlara ulaşmağa çaba gösterecektir :

"Ự̧ büyük tek Tanrlı dinlerin...kendine özgü manevı̊ ve dinsel çıkarlarını korumak...

"Kentin tüm sakinleri arasında işbirliğini geliştirmek... "Vesâyet Kurulu Kudüs Kentine bir vali atayacaktır...

"Yöresel özerk birimler...yöresel hükûmet ve yönetimin geniş yetkilerine sahip olacaktır...

"Kudüs Kenti askersizleştirilecek, tarafsılıı̆ı̆ ilân edilecek ve korunacak, sınırlan içinde yarı-askerî birliklere, onların talimlerine ya da eylemlerine izin verilmeyecektir.

“... Vali özel bir polis kuvveti oluşturacaktır...

“... Bir Yasama Kurulunun yasa çlkarma ve vergi toplama yetkileri olacaktir...

“... Statü bağımsız bir adalet sistemi kuracaktır...

"Arap̧̧a ve İbranice kentin resmî dilleri olacaktır...

“... Kentin sakinleri, inanç, din ve tapınma, dil, eğitim, söz ve basın; toplantı ve dernek kurma ve dilekçe hakları da dahil olmak üzere, insan haklari ve temel özgürlüklerinden yararlanacaklardur. Sakinler arasinda irk, din, dil ve cinsten ötürü hiçbir çeşit ayrum yapılmayacaktır...Her toplum kendi üyelerini kendi okullarında kendi dilleriyle eğitecektir...

“...Kutsal Yerler'den özgürce yararlanacaktır...Kutsal Yerler ve dinsel yapllar ya da mahaller korunacaktır. Onlarm kutsal niteliğini bozacak hiçbir eyleme izin verilmeyecektir..."

Bu Statü on yll yürürlükte kalacak, bu süre sonunda Vesâyet Kurulu durumu bir daha değerlendirecek ve kent sakinleri rejimde istedikleri değişiklikleri referandumla belirteceklerdi. $\mathrm{Bu}$ maddeler Birleşmiş Milletler'in garantisi altında olacak, Genel Kurulun onayı olmadan hiçbir değişiklik yapılmayacaktı.

Arap devletleri bu kararı kabul etmediler. Araplar Kudüs'ün uluslararası duruma sokulmasından da yana değillerdi. Kudüs'ün herşeyden önce bir Arap kenti olduğuna dair olan hukukî görüşler Temmuz 
1967'de Cezayir'de yer alan Arap Hukukçular Seminerinde ifade edildi. Bir kentin uluslararası duruma sokulabilmesi için, Tanca ve Triyeste örneklerinde olduğu gibi, ortada bir andlaşmanın ve kent sakinlerinin egemenliğl devretmek istediklerini gösteren bir iradenin bulunması gerekiyordu. Kudüs'ün durumunda böyle birşey olmamıştı. Oysa, Birleşmiş Milletler, üyelerinin herhangi biri gibi, toprak bütünlüğü ve egemenliği ilkesine saygı göstermek zorundaydı.

Filistin'i bölen kararın Kudüs için tasarladığı uluslararası rejim gerçekleşmedi -Arap tepkisinden ötürü değil, Kudüs'ün (ve Filistin' in) geleceği kuvvete başvurularak çizildiğinden dolayı...Israil kuruluş tarihi olan 15 Mayıs 1948'den önce ya da sonra, Birleşmiş Milletler'in çizdiği haritaya saygı göstermedi. Yahudi devleti toprağı olarak bilinen bölgeyi işgâl etttiği gibi, gene önerilen Arap devletine ait olacak toprakların önemli bir bölümüne de el koydu. Kudüs'ün batı (yeni) kesimi, Batı Galile, Kudüs ile Alkdeniz arasında kalan topraklar, Caffa, Akra, Lidda ve Ramle (Arap) kentleri ve yüzlerce Arap köyü ve kasabası eline böyle geçti. İsrail'in 1948 ve 1949 ynllarında işgâl ettiği topraklar 20.850 kilometre kare tutmaktadır. Filistin'in tüm yüzölçümü ise, $26.323 \mathrm{~km} .{ }^{2}$ dir. Böylece, İsrail Birleşmiş Milletler'in kendine ayırdı̆̆ $14.500 \mathrm{~km} .{ }^{2}$ ye $6350 \mathrm{~km} .^{2}$ ekleyerek önerilen Arap devletinden de yüzde 54'lük bir kesinti yapmış oluyordu. Böylece, o Arap devletinin yüzölçümü de 11.800 'den $5.400 \mathrm{~km}$.' ye iniyordu. 1949 'da, İsrail Filistin'in yaklaşık yüzde 80'ini elinde bulunduruyordu. Oysa, Manda yönetimi son erdiğinde, Yahudilerin elindeki topraklar ancak \%6 kadardl.

İsrail'in önce Hagana ve Irgun gibi terör örgütleri yoluyla, sonra da savaşla elde ettiği topraklar üstünde hukuken bir sahipliği olamaz. İsrail Kudüs'ün bir kısmına silâh zoruyla girerken, doğu kısminı da Ưrdün işgâl etti. Bu bölünmenin $30 \mathrm{Kasım} 1948$ İsrail-Ứrdün ateş-kes andlaşması ile 3 Nisan 1949 mütakere andlaşmasında da sözü edilmektedir. Ne var ki, böyle bir bölünme hukuken egemenlikten vazgeçme anlamina gelmez.

Kudüs'ün İsrail ve Ürdün kuvvetlerince işgâli Birleşmiş Millețler' in bu kenti uluslararası bir rejime kavuşturma çabalannı durdurmadi. Ilk B.M. Filistin Arabulucusu Kont Folke Bernadotte 16 Eylül 1948' de, Arap ve Yahudi toplumlarına yöresel özerklik vermek koşuluyla, Kudüs'ün etkin B.M. denetimine sokulmasını istedi. ${ }^{10}$ Genel Kurul da 11 Arallk 1948 tarihli ve 194 (III) numaralı kararında "mevcut haklar"

10 a.5.k. 
ilkesine uyulmasinı bir kez daha isteyerek, sürekli bir uluslararası rejime yönelik öneriler getirmekle görevlendirilecek olan bir Filistin Uzlaştırma Komisyonu (CCP) kurulmasını temenni etti. Kısaca, Genel Kurulun 181 ve 194 numaralı kararları Kudüs için özel bir statü istiyorlard1.

Öte yandan, İsrail kentin işgâl ettiği batı kısmma hızla sahip çıkmaktaydı. İsrail Yüksek Mahkemesi Eylül 1948'de Yeni Kudüs'e yerleşti. Şubat 1949 'da da İsrail Meclisi "Knesset" orada toplandl; Devlet Başkanı bu kentte yemin etti. Anlaşllan İsrail Filistin'i bölen kararın işine yarayan maddelerine uyuyor, yaramayanları ise yok sayıyordu. Kendi varlığını 181 numaralı karara dayandırırken, aynı kararın öngördüğü Arap devletini tanımıyor, onun topraklarını da ele geçirmeğe çabalıyordu. Bu durumda, Genel Kurul 303 (IV) numaralı karan alarak daha önceki iki karara atıfta bulundu ve Vesâyet Kurulundan Kưüs'ün statüsüne ilişkin çalışmayı tamamlamayı ve uygulamaya başlamay istedi.

\section{İSRAIL'IN B.M.'DE KOŞULLU ÜYELİ̈I :}

İsrail Birleşmiş Milletler'e üye olmadan önce, işgâl ettiği topraklara ilişkin tavrı esnekti. Bu tavir üye olduktan sonra değişti. Önce, İsrail'in B.M.'e üye olması meşruluğunun tanınması anlamına gelmez. Örgütte üyeliğín üye devletlerce karşıllkl tanıma anlamına gelmediği daha Milletler Cemiyeti deneyinde kabul edilmişti. Aynı ilke Birleşmiş Milletler'de de geçerlidir. B.M.'in meşru olmayan bir devlete meşruluk kazandırma yetkisi de yoktur. Üyelik için örgütün sorumluluklarını taşımağa "yetenekli ve istekli" olma koşulu arandığı B.M. Andlaşmasında yazılıdır. İsrail'in durumunda önemli olan, bu devletin B.M. üyeliğinin bazı koşullara bağll olarak kabul edilmiş olduğu gerçeğidir. Bu koşullar İsrail'in 29 Kasım 1947 ve 11 Aralı 1949 tarihli olanlar başta olmak üzere, Birleşmiş Milletler kararlarını kabul etmesi zorunluluğudur. Bu iki karar da, İsrail'e, Kudüs'ün statüsü de dahil olmak üzere, birtakım sorumluluklar yüklüyor. Bu noktada anımsamak gerekir ki, İsrail'in üyelik için ilk başvurusu Güvenlik Kurulunca 17 Aralık 1948 tarihinde reddedilmişti. İsrail başvuruyu yenileyince, Genel Kurul kararlarının kabulü konusundaki tavrını açıklığa kavuşturmak amaciyla temsilcisini dinlemek istedi. İsrail temsilcisi 1947 tarihli Genel Kurul kararına uyacağına dair kesin ve açı sözlü güvence verdi. ${ }^{11}$ Daha sonra İsrail $D_{1}$ Is İşleri Bakanı olan temsilci Abba

11 Official Reconds of the 3rd Session of the General Assembly, Ad Hoc Political Committee, Part II, s. 302. 
Eban Kudüs sorunu sözkonusu olduğunda İsrail Hükûmetinin bu sorunun B.M. Andlaşması Madde 2/7'ye göre, "ulusal yetki" içine sokulup sokulmayacağına dair bir soruya verdiği yanıt bugün resmî B.M. belgelerindedir: "Kudüs'ün hukuksal statüsü İsrail'in egemenliği altındaki topraklardan değişik olduğu için, B.M. Andlaşması Madde 2/7' nin Kudüs sorununa uygulanabileceğini düşünemiyorum..."12 Küba delegesi de tartışma ve konuşmaları özetlerken, İsrail'in Kudüs'ün uluslararası duruma sokulması yönünde garantiler verdiğ̣ini yineledi ve bu değerlendirme de zabitlara geçti.13

İsrail'i 11 Mayis 1949'da üye olarak kabul eden 273 numaralı kararın içinde de üyelik koşuluna açık atıflar vardır. Bu karar daha önceki 1947 ve 1948 tarihli kararlara İsrail'in uyacağına dair özel komite önünde temsilcisinin verdiği söz ve garantileri hatırlatmaktadır.

Bu durumda, İsrail'in B.M. üyeliği verdiği sözlere bağlı kalmasıyla olasıdır. İsrail'in bu örgüt içindeki statüsü başka hiçbir devletinkine benzemez. İsrail B.M. Genel Kurulu kararının bir yaratığıdır. Ve bu karar İsrail'in uymak zorunda olduğu birtakım sınırlamaları da birlikte getiriyor. İsrail kendi varlığını borçlu olduğu kararı çiğneyemez. Ama Knesset 23 Ocak 1950'de Yeni Kudüs'ü İsrail'in başkenti ilân etmiş ve 1951'de İsrail Bakanlar Kurulu, bakanlıklarıyla birlikte buraya taşınmıştır. Böylece, Vesâyet Kurulu'nun Kudüs için hazırladığı Statü de, Filistin Uzlaştırma Komisyonunun önerileri de bir yana 1tilmiştır.

\section{SALDIRISI :}

1950'den 1967'ye kadar Kudüs Ürdün ile İsrail arasında bölünmüş olarak kaldı. Bu yıllarda İsrailliler kentin eski bölümündeki Kutsal Yerler'den yararlanamadılar. 1966 yılı İsrail'in yeni bir savaşa hazırlandığına dair göstergelerle doluydu. Batı kamu oyunun o tarihlerde neden yalnız İsrail'in "güvenliği" açısından duyarlı olduğu ve 1967 yllının niçin bu Siyonist devlet için bir saldırı ve genişleme fırsatı olarak değerlendirildiği gibi ilginç noktaların incelenmesi de konumuz dışında kalıyor.

Biz gene Kudüs'e dönelim. İsrail 15 Mayıs 1967'de, Birleşmiş Milletler kararlarına ve Ürdün ile yapmış olduğu mütakere andlaşmasına aykırı olarak Kudüs'te askerî bir geçit resmi düzenledi. 5 Haziran'da da önce Mısır'a saldırdı, sonra da Ưrdün ve Suriye ile savaşa tutuştu.

12 a.g.k., s. 286-287.

13 a.g.k., S. 351. 
İsrail'in iki gün sonra Doğu (eski) Kudüs'te de egemen olması bu kentin geleceği üstünde çok ciddî etkiler yaptı. İsrail, askerleri ve silâhlarıyla Kudüs'ün bu kesimine de girdikten sonra, General Moşe Dayan şunları söylüyordu: "Kudüs'ü kurtarduk; İsrail'in başkenti olan parçălanmış kenti birleştirdik. Bu en kutsal anıta, bir daha ayrılmamak üzere, döndük."14

Ertesi gün, Kudüs'ün 1967'den önce İsrail'in işgâl etmiş oldư̆u batı kesiminin yönetiminden sorumlu olan belediye meclisi kent plânunın bu kez işgâl edilen doğu kesimini de içine alacak biçimde genişletilmesini kabul etti. 15 Haziranda, Israil Kabinesi kentin önceden Ưrdün işgâli altında olan bölümünü de İsrail devletinin bir parçası sayan özel bir yasa maddesini gündemine aldı. Filistinli Arapların konutlarından çıkarılma işlemi başlamıştı bile. ${ }^{15} 20$ Haziranda, David Ben-Gurion Jerusalem Post'a yaptığı bir açıklamada Kudüs'ün Kral Dâvud'un günlerinde "İsrail başkenti" olduğunu ve bundan böyle de "ilelebet" başkent kalacağını söyledi. Bir hafta sonra, Knesset'in aldiğı yeni bir karar hükûmete işgâl ettiği topraklara kendi yönetimini ve yasalarını götürme hakkı veriyondu. 29 Haziranda, İsrail Ordusunun bir emri de Arap Kudüs'ün halkı tarafından seçilmiş olan Belediye Meclisini dağıttı, Belediye Başkanını görevden aldı ve Arap Belediyesinin eski çalışanlarını İsrail Belediyesine atadı.

İsrail'in "Kudüs'ü birleştirme" yaftası altında attığı bu ilk adımlar, aslında, bu kentin ilhakı ve Yahudileştirilmesi çabalarından başka bir şey değildi. Ancak bu girişimler hem İsrall'in içinde, hem de dış ülkelerde tepkilere ve karşı koymalara yol açtı. Batı (Ağlama) Duvarı'nın hemen önündeki tarihî Mağribî mahallesi, duvar önünde tapınacaklara ve turistlerin otomobillerine park yeri açma sözde nedeniyle yıktırıldı. Yalnız kentin. eski görünümü hızla değ́işmekle kalmıyor, tarihten gelen birikimle yerleşmiş haklar peşpeşe ve saygısızca çiğneniyordu. Batı Kudüs'ün Siyonist Belediye Başkanı Teddy Kollek, 1967 saldırısından çok önce, kentin Yahudi kısmındaki gelişme tasarıları ve trafik düzenini doğu yakasının da birgün işgâl ve ilhak edileceği düşüncesinden hareketle ona göre hazırlatmıştı. Hernekadar General Dayan Kudüs'e girildiği gün bir askerin Kubbet el-Sahra'nın tepesine diktił̆i İsrail bayrağını aşağı indirtmişse de, bu jest temel gerçeğı gizleyemez. Ağlama Duvan Yahudiler için olduğu kadar, Harâm el-Şerîf' in bir parçası olması nedeniyle Müslümanlar için de önemlidir. 1930' da Uluslararası Araştırma Komisyonunun vardığı sonuçlar da orta-

14 Facts on File, June 8, 1987.

15 UPI Dispatch, June 19, 1867. 
dadır. Kudüs'ün tarihi ve tarih içinde Müslümanların tavrı Araplara yapılan bu muamelenin haksızlığını göstermektedir. Bu incelemenin baş tarafında Halife Ömer'in herkesin hakkuna, hukukuna nasll saygilı davrandiğı anlatıldı. Başka zamanlarda bir elden bir başkasına kana boğularak geçen bu kent böylesine uygarca sahip değiştirmişti. Eyyubî de Huristiyanlar ilgilendiren Kutsal Yerler'i, kılıcıyla muzaffer olduğu zaman bile, gene onlarn denetiminde bıraktı. Filistin ve Kudüs daha Osmanlı Türklerinin egemenliğindeyken ve Ingiliz Manda yönetiminin kurulmasına daha yıllar varken, Siyonistler ya açıkfa ya da el altından yaptıklarıyla haklarından fazlasının peşinde olduklarinı gösteriyorlardı. Birinci Cihan Savaşının sonlamna doğru, İngiliz Ordusundaki Yahudi birliğinin yaptığı ilk işlerden biri Ağlama Duvarı'nın önünde safa durmak olmuştu. Israil'in daha sonra Devlet Başkan olacak olan ünlü Siyonist Chaim Weizmann da Lord Balfour'a yazdığı bir mektupta, "en kutsal kentimizin en kutsal anitı ne idiğü belirsiz Magriblilerin" "16 elinde diye şikâyette bulunduktar sonra Ağlama Duvan'nın kendilerine teslimini istemişti. Bilindiği gibi, Weizmann'ın haksızca "ne idiğü belirsiz" diye tanımlamayı yeğlediği Mağribliler oraya Eyyubî'nin oğlu tarafından yerleştirilmiş olup 700 yıldan beri kesintisiz orada yaşıorlardi.

Çıplak gerçek şu ki, General Dayan Kubbet el-Sahra'nın tepesine dikilen İsrail bayrağını kendi emriyle oradan indirtmişse de, onun_bu emrini de, uluslararası komisyonun yasalaşan kararını da, uluslararası toplumun iradesini de, yüzylları kapsayan Müslüman tarihini de Israil buldozerleri çiğnedi. Eyyubî'nin oğlunun yerleştirdiği Mağribilerin torunları 11 Haziran sabahı birkaç dakika içinde konutlarından dişarı atılıverdiler. Kudüs'ü yalnız ve yalnız bir "Yahudi kenti" sarısı hızla uygulanıyordu. O kadar ki, Kral Salamon'un Tapınağını bulup çıkarma çabası yıllar sonra onun yıkıntıları üstüne yapıldığına inanllan Kubbet el-Sahra'yı temellerinden sarsmağa başladı. Müslümanlıktan kalma anıtlar hiçbir zaman bu denli küçümsenmemişti. Dünya kültürünün de ayrılmaz parçası saylan bu yapılar yıkılma tehlikesiyle karşlaş̧rken, Ağlama Duvarı'nın dibine sağlamlaştırmak̀ için çakılan birkaç çivi tüm duyarl Yahudi çevrelerini ayağa kaldırıyordu. Geçmişte, Yahudiliğin haklarının çiğnendiği de olmuştu. Ancak; Israil bu olayları yer yer abartarak dünya kamu oyunun önüne getirmek için elinden geleni yaptı ve çok da başarılı oldu. Örneğin, İsrail propagandası Doğu Kudüs Ürdün yönetimindeyken Yahudi me-

\footnotetext{
16 A.L. Tibawi, Jerusalem : Its Place in Islam and Arab History, Beirut, the Institute for Palestine Studies, 1988, s. 32.

17 Time. March 1, 1971.
} 
zarlıklarının harap edildiklerini tüm dünyaya duyurdu. Ancak, kaç mezarlığın saldıriya hedef olduğu kolayca saptanabilecekken, aradan yıllar geçtikten sonra bile, resmî rakamı bazan 34, bazan da 58 olarak vermektedir. ${ }^{18}$ Havralarm da Araplar tarafindan top ateşine tutulduklarına dair propaganda büyük bir abartmadır. Önce, Dogu Kudüs'te bildiğimiz anlamđa Havra diyebileceğimiz üç-dört yapı vardır. Gerisi o tarihlerde Araplardan kiralanmış ve Yahudilerin gelip geçerken kullandıkları tek odacıklardı. Bundan bosska, Siyonist militanlar havraların en yüksek noktalarını, kente egemen oldukları için, bir mevzi olarak kullanıyorlard.. Ingiliz Glubb Paşa, anılarında, 1948 savaşında Arapların Siyonistlerden havraların askerî amaçlar için kullanılmamasını istediklerini ve bunlardan ateş edildiğinde bile birkaç kez intar ederek olumlu bir yanit alamadiktan ancak kırk-sekiz saat sonra gereken tepkiyi gösterdiklerini yazıyor. ${ }^{19}$ Ama bugün turistlere gösterilenler havralardaki deliklerdir yalnızca. El kitaplarında yazllanlar da konunun asil ayrintisina girmiyor.

Ama İsrail Kudüs'ün tümünü işgâl ettikten sonra eline geçen mezarlıklara neler yaptığına bir bakalım. Örneğin, bir Yahudi mezarlığı diye kayıtlara geçirilen Mamillah On-altıncı Yüzyılda vakıf'tan kiralanmış olan bir Müslüman mülküdür. Üstelik, Müslümanlık kadar eskidir de. Peygamberin çevresindekilerden bazilarının orada gömülü oldukları söylenir. Ama bugün, bu gömüt yeri hemen hemen yok olmuştur. İsrail Belediyesinin buldozerleri önce mezar taşlarını ve toprağa karışarak çıkan kemikleri önüne katıp sürmüş, daha sonra aynı yer otomobil park yeri durumuna getirilmiş, çevreye birkaç ağaç ve çiçek dikilmiş, bir köşeye de genel bir yüz-numara oturtulmuştur.

David Ben-Gurion'un Paris ne denli Fransiz ve Londra ne derece Ingilizse, Kudüs'ün de aynı ölçüde Yahudi olduğuna dair sözü tarihe ve hukuka ne kadar aykırıysa, Kutsal Yerler'in korunduğuna dair Ísrail propagandası da, özü ve ayrıntıları açısından, yanıltıcıdır. ${ }^{20}$ İslâm ve onun temsil ettiği kültür ve herşey Müslümanlık için önemli olan bir kentte açıkca ve hukuk kuralları çiğnenerek hakarete uğramaktadır. Kudüs'ün bir yönüyle Yahudiler için de kutsal olması başka, ama farklı din ve kültürleri temsil edenlerin haklarmın ayaklar altına alınması gene başkadır. Bugün, El-Aksa'da ve Kubbet ei-Sahra çevresinde bulunan Arapların hemen yakındaki genişletilmiş Ağlama Duvarı'ndan gelen karışık mirıltılar ve yükselen ilâhilerle dua-

18 The Guardian, September 17, 1871 ve May 9, 1872.

19 J.B. Glubb, A Soldier with the Arabs, London, Hodder and Stoughton, 1957, s. 129.

20 Israel, Ministry of Foreign Affairs, Facts About Israel : 1870, Jerusalem, Keter Books, 1970, s. 25. 
larını bile şaşırdıklan bir gerçektir. Müslümanlığın bir simgesi olan Harâm el-Şerif'in gün geçtikçe işlevi azalmakta, yeni ve yabancı çevrenin mengenesi içinde boğulmaktadır.

İsrail'in tarihten gelen geleneklere ve başkalannın hukukuna saygilı olduğuna dair resmî savunmalar sistemli Yahudileştirme kampanyası karşısında bir propaganda çizgisini aşamıyor. Örneğin, Mağribi Mahallesi yerle-bir edildikten sonra, Ağlama Duvarı çevresinde 82 metrelik bir yerin "temizleneceği" söylenmiş ve, İslâm Kurulunun protestolarn dikkate alınmayarak, Duvar'ın güney bölümünde arkeolojik kazılar başlatılmıştı. Bunun bir sonucu olarak, Şâfî Müftülüğünün resmí konutunda, onun yakınındaki camide ve çevrenin on-cört evinde çatlamalar olmuş, sonuçta tüm bu yapılar yıkılma tehlikesi. öne sürülerek boşaltılmıştı. Kuzeyde de Kubbet el-Silsile yakınında bombalar bulunduğu ileri sürülerek eski El-Tankiziye Okulu da dahil olmak üzere, Arap çevresine el konmuştu. Oysa, Araplar Siyonistlerin bu değişikliği yapabilmek için, sözünü ettikleri bombaları kendilerinin yerleştirdiklerini söylemektedirler.

Siyonizmin bu "tertipçiliğine" bazan kaba bir alay da katmaktadur. 29 Haziran 1967'de, İsrail Askerî Komutanlığı, Arap Beleđiye Meclisinin dağıtıldığını haber verirken, Doğu Kudüs Belediye Başkanı Ruhi El-Hatib'e yazdığı resmî yazıda Arap temsilciliğinin bundan böyle olmayacağını "bildirmekle kesbişeref eylediğini" söylüyordu. Hemen ardından, Arap bankaları kapatıldı, paralarına el kondu. Kentin her yanında İsrail parası geçerli oldu, İsrail vergi sistemi uygulanmağa başlandı. Tüccarlar, zanaatkârlar ve meslek sahiplerinin iş̧âlcilerden resmen izin almaları zorunluluğu kondu. Devlet okulları İsrail eğitim programını izlemekle görevlendirildi. Mahkemelerde İsrail yasaları uygulanmağa başlandı. Böylece, Kudüs toprağı, mülkü, ekonomisi ve Kudüs yurttaşı yoğun bir Yahudileştirme çabası içine sokuluyordu.

Bir İsrail yöneticisi "önce toprağa el koyuyoruz; yasalar onu izliyor" demişti.21 İsrail propagandası el konan bazı özel topraklar için yüksek tazminat ödendiğini ileri sürüyor. Herhangi bir ödemenin sözkonusu olduğu durumlarda, rakam çoğu kez 1948 yılı değerlerini aşmiyor ki, bu da düpedüz bir göstermeliktir. Yoksa, İsrail buldozerlerinin Araplara ait yapları her fırsattan yararlanarak gelişigüzel yıktıkları artık bilinmelidir. Bazan çarşıya, pazar gitmiş olan bir aile dönüşünde, konutunu yıkılmıs buluyor, durdurma emri için Belediye Başka-

21 David Hirst. "Rush to Annexation: Israel in Jerusalem," Journal of Palestine Studies, C. III, No. 4 (Summer 1974), s. 19. 
nuyla görüşmeğe giden ev sahibi geri geldiğinde gene aynı sonuçla karşlaşıyor. Direnen Araplar, çoğu kez, konutlarınun önce giriş basamaklarının sökülüp atıldığın, sonra sırasıyla kaldırım, bahçe, hattâ odaların bir kısmının yıkıldığın görüyorlar. Boyun eğmēyenler üstünde baskı, hattâ işkencelere başvuruluyor. Bugün, buldozer yeni Kudüs'ün neredeyse bir simgesi olmus durumda.

Ve yıkılan yalnız elle tutulur yaplar da değil. Okula giden $\mathrm{Ku}-$ düslü Arap öğrenci kendi kültür, tarih ve dinini İsrail gözüyle görüp değerlendirmek zorunda bırakıllyor. Arap tarihi onlara bir yağma ve çekişme olarak, Yahudi geçmişi de parıltılı bir biçimde sunuluyor. Müslümanlık ve Huristiyanlık hiç okutulmazken Tevrat'ın ögretiminin zorunlu olduğu orta okullarda Arap öğrenci kendi tarihini 32, Yahudilerin tarihini ise 384 saat görüyor. Osmanlı yönetiminde parlak bir okul olan Raşidiye'de 1967'den önce bile 800 ögrenci varken, 1970' lerde bu sayı 14'e inmişti.

Kendi kişiliği olan ve bu kişilikle dünyanın saylı kentleri içinde seçkin bir yeri bulunan Kudüs sanki bir Minnesota kasabası, bir Los Angeles banliyösüymüş gibi görünüm ve ruh değiştiriyor. Bu değişikliklerin tümü devletler hukukuna, Birleşmiş Milletler'in kararlanna ve İsrail'in B.M.'e üye kabul edilmesinden önce verdiği sözlere aykın düşmektedir. Bunun böyle olduğunu gösteren çeşitli B.M. belgeleri, ${ }^{22}$ monograflar ${ }^{23}$ ve ilk-elden tanuklar ${ }^{24}$ var. Bu kaynakların hepsi İsrail'in eylemlerinin hukuk-dışı olduğunu gözler önüne seriyor.

Kudüs'ün Arap halkı Kudüs'ün (ya da Filistin'in herhangi bir parçasının) başka birine ait olmasına dair hiçbir rıza göstermiş değildir; askerî işgâlcinin egemenliğini de hiçbir zaman tanımamıştır.

\section{BİLEŞMIŞ MILLETLER KARARLARI :}

1967 saldırısı ve İsrail'in Kudüs'te aldığı ilk önlemlerden hemen sonra, Birleşmiş Milletler Genel Kurulu 4 Temmuz 1967 tarihli ve 2253 sayılı kararıyla, İsrail'in kentin statüsünü dę̆iştirme amacıyla aldığı önlemlerden duyduğu endişeyi belirterek, bu önlemlerin geçersiz olduğunu ilân etti ve Israil'den attığı adımlardan geri dönmesini ve ay-

22 Örneğin : A/6793, A/8797, S/8146 ve S/8158.

23 Rouhi Al-Khatib. The Judaization of Jerusalem, Beirut, P.L.O., 1970. Yazar Doğu Kudüs'ün ülkesinden çikanlan Belediye Başkanıdır.

24 Marie-Therese, War in Jerusalem, Amman, 1967; WJ. Stibbe, The Other Side of the Story, Amman, 1967; John Carter, An Eyewitness in Jerusalem: Spring 1969. London, the Jerusalem Committee, 1968. 
nı yönde yenilerini atmamasinı istedi. Gene Genel Kurul on gün sonra aldığ 2254 numaralı kararda İsrail'i bir önceki karara uymamakla kınayarak Kudüs'ün statüsünü değiştirecek önlemlerden vazgeçmesini bir kez daha istedi.

Birleşmiş Milletler Güvenlik Kurulu'nun 1967 saldırısından sonra aldığı ilk karar 22 Kasım 1967 tarihli ve 242 sayılı ünlü karardır. Bu karar, kuşkusuz, 1967 savaşından sonraki güç dağılımını, yåni askerí bakımdan muzaffer olan İsrail ile yenik Mısır, Suriye ve Ürdün'ün durumlannı önemli ölçüde yansıtır. Arap ülkeleri İsrail'in işgâl edilmiş topraklardan çekilmelerini isterlerken, İsrail yeni "savunulabilir" s1nurlar istemiş, ama bunun ne olduğunu, nerelerden geçtiğini bugüne değin belirtmemiştir. Ancak, Filistin sahnesine yeni bir öğe girmiştir. Bu da Filistin halkının tek meşru temsilcisi olan Filistin Kurtuluş Örgütü'dür. Saygın bir uluslararası konumu olan F.K.Ö., Birleşmiş Milletler dahil, birçok uluslararası kuruluşlara da kabul edilmiştir. $\mathrm{Bu}$ nedenle, Güvenlik Kurulu'nun 242 sayll karan bugünkü gụ̧̈ dağll1minı gerçekçi olarak yansıtmıyor. Ancak, gene de, salt hukuk açısından, 242 sayılı kararda da "savaş yoluyla toprak kazanmanın kabul edilemeyeceği" belirtiliyor. Bu temel kural Kudüs'e de, Filistin'in herhangi bir yerine de pekâla uygulanabilir. Gene de aynı karar Kudüs' ün adını açıkca geçirmiyor.

Güvenlik Kurulunda Kudüs'le ilgili olarak 1968'e kadar karar alınmadi. 21 Mayıs 1968 tarihli ve 252 sayll karar İsrail'i Genel $\mathrm{Ku}$ rulun son iki kararına uymamakla suçluyor, Israil'in Kudüs'ün hukukî statüsünü değiştirmek amacıyla, topraklara ve mülke el. koymak da dahil olmak üzere, yasama ve yürütme alanındaki tüm eylemlerinin geçersiz olup bu statüyü değiştiremeyeceğini söylüyor ve İsrail'i böylesine önlemlerden vazgeçmeğe ve bu yönde yeni önlemler almamağa çă̆ırıyordu. İsrail bu kararı da hiçe sayınca, gene Güvenlik Kurulu 3 Temmuz 1969'da 267. sayılı kararı aldı. Hukukî açıdan iki karar da birbirine benzemekle birlikte, ikincisi daha sert bir dil kullanyordu.

21 Ağustos 1969 'da bütün dünya Kudüs'ün incilerinden biri olan El-Aksa Camiinde çıkan yangınla sarsıldı. Yapının güney bölümü, kubbe, süslemeli tavan ve ünlü minber yanmış, başka şeyler de zarar görmüştü. İsrail Hükûmeti yangına neden olan kişinin aklî dengesinin yerinde olmadığını ileri sürdü. Güvenlik Kurulu'nun 15 Eylül 1969 tarihli ve 271 sayılı kararı bu olay nedeniyle alınmıştı. Kurul kutsal bir yapı olan El-Aksa Camiine yönelen bu saldırınin da bir kez daha ortaya koyduğu gibi, İsrail'in bir an önce izleyegeldiği tutumdan vazgeçmesini istedi, 298 sayılı karar da (25 Eylül 1971) aynı biçimde bir hatırlat- 
mayd. 22 Mart 1979 tarihli ve 446 say?hl karar, Kudüs de dahil olmak üzere, 1967'de işgâl edilmiş olan Arap topraklarındaki yerleşmeleri incelemek için üç kişilik bir komisyon kurdu. İsrail bu komisyonu Filistin'e sokmadı bile. 1 Mart 1980'de alınan 465 sayll karar İsrail'i komisyonla işbirliğine çağırdı.

Özetle, Birleşmiş Milletler'in 1967'den sonra aldığı kararlar, İsrail' in bu saldırıyı izleyip eylemlerini vurgulamakla birlikte, Kudüs'ün ilhakına ve Yahudileştirilmesine karşı çıkmaktadır.

\section{CENEVRE ANDLAŞMALARI :}

Israil'in Kudüs'teki eylemleri B.M. kararlarına aykırı olduğu gibi, 1949 Cenevre Andlaşmalarına aykırıdır. Bunların "Savaş Zamanında Sivillerin Korunmasına İlişkin Cenevre Konvansiyonu" başlığını taşıyan dördüncüsü İkinci Cihan Savaşında sivillere yapılan bazı muameleleri ilerde önlemek amacını güdüyordu.

Israil (temsilcisinin 26 Ekim 1977'de B.M. Genel Kurulu'nda söylediği gibi25) Dördüncü Cenevre Andlaşmasının Batı Yakasına (bu arada, Kudüs'e) uygulanamayacağı inancindandır. Bunun nedeni de Ürdün'ü burada "meşru egemen devlet" olarak görmemesi ve kendini de işgâlci taraf saymamasıdır. İsrail'e göre, devletler hukukunda "işgâlci taraf" ve "işgâl edilmiş toprak" belirli anlamları olan teknik kavramlar ve kelimelerdir; iki devletin silâhlı çatışmasının bir sonucu olarak, birinin ötekinin egemenliğindeki toprağı denetimi altına almasi demektir; bu durumda, meşru olarak egemen olan devlet, fiilen denetimi ortadan kalksa bile, o toprak üstündeki egemenliği devam eder; İsrail'e göre, sözkonusu topraklarda meşru egemenliğin ortadan kalkarak yerine bir işgâlci devletin gelmesi olayı yer almamıştır, çünkü Ürdün bu topraklarda meşru olarak hiçbir zaman egemen olmamıs, oralarda bir işgâlci olarak bulunmuştur; meşru egemen devletin olmadığı yerde de Dördüncü Cenevre Andlaşmasının maddelerinin uygulanması beklenemez. İşte, İsrail'in görüşü budur. Hattâ İsrail bu maddelerin Filistin'in herhangi bir yeri için bile uygulanamayacakları görüşünü savunuyor.

Ancak, böyle bir savunma kabul edilemez - ve edilmemiştir de. Önce, sözkonusu ạndlaşma tüm Orta Doğu ülkeleri tarafından imzalanmıs ve Anayasalarında gösterilen yöntemlere uygun olarak onaylanmıştır. Bu andlaşmayı İsrail'de kabul etmiş ve 6 Ocak 1952 tarihin-

25 U.N., Document A/32/PV. 47, s. 46-48. 
de onaylamıştır. Böylece, bu andlaşma bütün bölge devletleri için hukuken bağlayıcıdır.

İkinci olarak, Andlaşmanun Birinci Maddesi "Taraflarm bu Konvansiyona bütün koşullarda saygı duyacaklarını ve saygı duyulmasını sağlayacaklarını" açıklamaktadır. Burada. iki önemli nokta var : Biri, andlaşmanın "tüm koşullarda" geçerli olduğu ve ikincisi de imzalayanlara sorumluluk yüklediğidir. Üstelik, bu sorumluluk yalnız her imzacl devletin andlaşmaya uyma noktasinda kendi başına duyacağ bir sorumlulukla sinırl değildir. Taraflar andlaşmaya "saygı duyacak ve saygı duyulmasın sağlayacaklardır (...undertake to respect and to ensure respect). Burada ince ve önemli bir nokta daha var: Andlaşmaya imza koymus ve onaylamış olan her devlet bu andlaşma hükümlerine yalnız kendi uymakla kalmayı başkasının da uymasını sağlamakla da yükümlüdür. Bu ikinci görevini de yapmadiğı takdirde, andlaşmayı gene çiğnemiş sayılır. İşte, bu nokta hepimize İsrail'i andlaşmaya uymağa zorlamak gibi bir görev veriyor.

İsrail Dördüncü Cenevre Andiaşmasını çiğnemiş midir ve çiğnemekte midir? İkinci Cihan Savaşının sonunda Nazi savaş suçluları muhakeme edilirken, onlar da "işgâl edilmiş toprak" sözcüklerine başka anlamlar vermeğe ve böylece devletler hukukunđan kaçmağa çabalamışlardı. 1949'da kabul edilmiş olan Cenevre Andlaşmaları işte bu türlü kaçamaklara olanak sağlamayacak bir biçimde yazılmak istendi. $\mathrm{Bu}$ nedenle, andlaşmanin hükümleri her türlü savaş ya da silâhlı çatışmaya uygulanabilir durumdadır. Hedefi herhangi bir çatışmada insan haklarnna saygı gösterilmesini sağlamaktır. Ürdün Batı Yakası'nı işgâl etmiş olsa bile, bu durum İsrail'e o topraklarda insan haklarnnı çiğneme hakkı vermez, çünkü Cenevre Andlaşmalarının amacı bir toprak parçası üstünde hangi tarafın egemen olduğunu saptamak ya da devletlerin çıkarlarını gözetmek değil, insan haklarının çiğnenmesini, sivillere insanlık-dışı muamele yapılmasını önlemektir. Bu hedefler çerçevesinde, İsrail Dördüncü Cenevre Andlaşmasını çiğnemiştir ve çiłnemektedir.

Ísrail Yüce Mahkemesi bu konvansiyonun andlaşmaya dayanan bir devletler hukuku olması nedeniyle, iç hukukla yani özel bir İsrail yasasıyla uygun bulunması koşulunu da öne sürmüşse de, İngiltere ve Amerika arasındaki "Alabama" örnek olayında da belirtildiği gibi, hukuksal araçların tamamlanmamıs olması ilgili tarafı sorumluluktan kurtarmaz.

Kısaca, bu andlaşmaların hedefi insancil bir ilkenin korunmasıdır. Nitekim, Birleşmiş Milletler de bunların İsrail işgâli altındaki böl- 
gelere uygulanabileceklerini belirtmiştir. Güvenlik Kurulu'nun $11 \mathrm{Ka}-$ sim 1976 ve Genel Kurul'un da Aralık 1978 tarihli kararları bu yöndedir. Birleşmiş Milletler Özel Komitesi'nin, Kızll Haç Uluslararası Komitesi'nin, Uluslararası Af Örgütü'nün, İsviçre Insan Hakları Birliği'nin ve (A.B.D.) Ulusal Hukukçular Birliği'nin araştırmaları ve vardıkları sonuçlar da bu yönde olmuştur.

Dördüncü Cenevre Andlaşmasının 49'uncu Maddesi sivil halkın yerinin değiştirilmesini yasaklarsa da, İsrail Filistinlileri yerlerinden etmiş, işgâl ettiği bölgelerde askerî ve sivil yerleşimler kurmuş, Kudüs'ün de çehresini değiştirmiştir. İşâl altındaki yerlerde böylesine bir demografik değişim Arap kültürünü yok etmek amacını da güdüyor. Böylesine sistemli bir çaba da devletler hukukuna aykındır. İsrail Hükûmeti yeni yerleşme merkezleri kurmakla da uluslararası andlışmalara ve Birleşmiş Milletler'in kararlarına karşl çıkmaktadır. 1967'den sonra askerî ve yari-askerî olan yerleşmeler, gün geçtikçe, sivil yerleşmeler durumuna sokulmaktadır. Kudüs (ve Sina) çevresindekiler de başından beri sivil nitelikteydiler.

İsrail'in bu Arap bölgelerine dışardan başkalarını getirip yerleştirmesinin bir önemli sonucu da su bunalımının yaratılmıs olması ve Arap su kaynaklarına el konmasıdır. Yahudi yerleşmelerinin çoğu tanmsal olduğu için, İsrail Arapların haklarını yana iterek kendi gereksinimine öncelik tanımaktadır. Bunun sonucu olarak, işgâl edilmiş bölgelerde su kaynaklarının denetimi de Dördüncü Cenevre Andlaşmasına aykım düşüyor. Filistinli, tsrail yetkililerinin izni olmadan kuyu bile açamamakta, mevcut Arap kuyularından çekilen sular ölçen araçlarla denetlenmektedir. İsrail'in yerleşme politikası uygulandıkça, hükûmetin sular üstündeki bu mengenesi de sıkılacaktır.

İsraillilerin Araplara yığınsal cezalar vermekte olduklarına dair çeşitli incelemeler vardır. Yığın halinde tutuklama, konutların yığınsal yıkımı ve Araplardan gelen protestolara karşı türlü yığınsal tepkiler gene Dördüncü Cenevre Andlaşmalarının 33 ve 53'üncü Maddelerine girmektedir. Aynı biçimde, 27, 30, 31 ve 32'nci Maddeler de işkenceyi ve kötü muameleyi yasaklar. Bu konuda da ikna edici raporlar vardır. Londra'da yayınlanan Sunday Times gazetesinin işkence konusundaki 17 Haziran 1977 tarihli raporu bu eylemin yüksek rütbeli İsrailli yöneticiler tarafından desteklendiø̆ini gösteriyor.

\section{SONUÇ :}

Konuya hukuk açısından bakıldığında, yazar Hedley V. Cooke ile birlikte şu yargıyı yineleyebiliriz: "Dünyadaki tüm ülkeler arasında 
yalnız İsrail devamlı ve güvenli olarak kendinin diyebileceği bir karı̧̧ toprağa bile sahip değildir."20

Ingiliz Manda yönetiminin sona ermesinden bu yana, Filistinli Araplar kendilerini Siyonist işgâle karşı savunmak için ellerinden geleni yaptılar. F.K.Ö.'nün kuruluşu (ve bu arada Ürdün'ün Batı Yakasunda egemenlikten vazgeçmesi) B.M. Genel Kumulunun Filistin halkının kendi geleceğini kendinin saptaması, ulusal bağımsızlığı ve egemenliğini onaylamasında önemli etken oldu.

Ulusların kendi geleceklerini kendilerinin saptamaları halkların emperyalizme tepkisinin bir ifadesidir. Bu hak B.M. Andlaşmasında da Madde $1 / 2$ ve 55'de belirtiliyor. B.M. Andlaşmasının yorumu üstünde de bir çeşit vesâyet kurmağa çalışan emperyalist devletler bu hakkı sinırlamak isteyerek onu kullanılacak bir hak olmaktan çok işlevsiz bir ilke gibi sunmayı yeğlemişlerdir. Ancak, Genel Kurulun 1950'de aldığ 421 sayılı kararı bu hakkı temel insan haklarından biri olarak sayar. "Sömürge Ülkeleri ve Halklarına Bağımsızlık Verilmesine İlişkin B.M. Bildirisi" de halkların yabancı boyunduruk, baskı ve sömürüye hedef olmalarının temel insan haklarının yadsinması anlamına geldiğini açıkladı. Birleşmiş Milletler yalnız 1961'de bu açıklamanın uygulanmasını izlemek amacıyla bir Özel Komisyon kurmakla kalmadı, ulusların kendi geleceklerini kendilerinin özgürce saptama hakkı içine doğal kaynaklarına sahip olmaları hakkını da kattı. Özellikle Birleşmiş Milletler komitelerinde yapllan incelemeler sonucu olarak, bu haklar uluslararası ilişkiler ve devletler hukukunun bağlayıcı ve emredici kuralları içine girmeğe de başladı. Filistin halkının sözü edilen temel haklara sahip olmasına engeller konduğu açıktır.

$\mathrm{Bu}$ engellerden önemli biri Camp David Çerçevesi diye bilinen ve bunu izleyen andlaşmalardır. Gene konumuzu "Kudüs ve Devletler Hukuku" olarak sunırlamıs olduğumuzdan, Camp David'in uzun bir eleştirisini burada yapacak değiliz. Ancak, bu andlaşma temelde İsrail Başbakanı Begin'in 28 Aralık 1977 önerilerinden çok farklı değildir. Bu andlaşmalar Filistin halkının bir kısmına haklarının ancak bir kısminı (örneğin, self-determination ve devlet kurma hakkı hariç) kendine ait olması gereken toprakların yalnızca bir kısmı üstünde vereceğini söylemekte, fakat bunun üstünde bile İsrail'in her aşamada vetosunu kabul etmektedir. Bu durumda, "özerklik" ve "Filistinlilerin katılması" birer aldatmacadan ibarettir. Bu aldatmacalar hukukla bağdaşmaz. Ancak, konumuz bakımından önemli olan Camp David

26 Israel : A Blessing and a Curse, London, Stevens, 1980, s. 188. 
Çerçevesinin işgâl edilmiş Kudüs'ü "kendi kendini yönetecek otorite" diye tanımlanan kavramın bile dışında tutmuş olmasıdır. Bu otoritenin Kudüs'teki toprak, mülk ve hak üstünde hiçbir sorumluluğu olmayacaktır. Açıktır ki, böylesine andlaşmalar devletler hukuku açısından da geçersizdir. Bu andlaşmalar Filistin halkının haklarını çił̆nemektedir. 1977 Viyana Andlaşmasının 77'nci Maddesi de yapılmıs olan bir andlaşma devletler hukukunun belirli bir kuralıyla çatışacak olursa geçersiz sayılacağını belirtiyor. Viyana Andlaşmasını incelemiş olan Uluslararası Hukuk Komisyonu da uluslarn kendi geleceklerini kendilerinin saptamaları hakkın devletler hukukunun belirli bir kuralı olarak benimsemiş durumdadır.

Filistinlilere temel haklarının verilmemiş olduğu bilinen bir gerçektir. Kudüs'le ilgili olarak Birleşmiş Milletler'in aldığ kararlar da ortadadır. Ísrail'in bunlara uymaması onları geçersiz kılmaz. Ancak, B.M.'in İsrail'i yalnızca suçlamakla kalması ve bundan ileri gidememesi bu devleti cesaretlendirmiş, saldırılarını arttırma ve başkalannin hukukunu çiğnemeyi sürdürme olanağı tanımıştır. Kudüs'te (ve Filistin'in tümünde) yapılmış olan yanlışlıkları düzeltme görevi en başta Birleşmiş Milletler'e düşer. Adalet ilkeleri ve devletler hukukuna uygun olarak, saldunları durdurma ve uluslararası barıs ve güvenligi sağlama onun görevidir. B.M. Andlaşmasının birçok maddeleri Güvenlik Kuruluna bu yönde türlü yetkiler tanımışlardır. Üstelik, İsrail konusunda Birleşmiş Milletler'e özel bir sorumluluk düşüyor, çünkü İsrail devleti onun yaratığıdır. Kudüs'ün gelecekteki statüsü ise, bağımsız bir Filistin Devletinin kurulması konusunun temel bir öğe olduğu genel bir Orta Doğu andlaşmasına bağlıdır. 